Final draft version

\title{
Can De-Growth Be Considered a Policy Option? \\ A Historical Note on Nicholas Georgescu-Roegen and the Club of Rome
}

\author{
FINAL DRAFT VERSION
}

\author{
Clément Levallois \\ ERIM, Rotterdam School of Management \& Erasmus Studio \\ Erasmus University, Room T10-16, Burg. Oudlaan 50, 3062 PA Rotterdam. \\ clevallois@rsm.nl
}

Version 5.1 - June 21, 2010.

\section{Accepted for publication in Ecological Economics}

\begin{abstract}
At a few months' interval, Georgescu-Roegen's The Entropy Law and the Economic Process (1971) and Meadows et al. Limits to Growth (1972) were published. Both emphasized the dangers of economic growth, and both drew negative reactions from mainstream economists. Relying on archival evidence, we show that Georgescu-Roegen and the Club of Rome developed strategies of mutual support, which would present them at first view as natural allies. Georgescu-Roegen actually became a member of the Club of Rome, while Dennis Meadows acknowledged the influence of Georgescu-Roegen's ideas on the founding members of the Club. But in the late 70's, the gap widened between Georgescu-Roegen's adamant defense of de-growth, and the Club of Rome's less firm view of "sustainable growth." This paper explores the process leading to the self-isolation of Georgescu-Roegen, by showing that beyond a shared acknowledgment that economic and biologic systems were interdependent, technological optimism and ambitions for the global management of growth were central to the Club of Rome, while GeorgescuRoegen's personal history led him to ignore those practicalities and judge that de-growth was inescapable.
\end{abstract}

Keywords: Nicholas Georgescu-Roegen; history of ecological economics; de-growth, Club of Rome 
Final draft version

In 1988, a few months before the publication of the inaugural issue of Ecological Economics, Robert Paxton from Elsevier asked Nicholas Georgescu-Roegen to confirm his participation to the editorial board of the journal. To which Georgescu-Roegen replied:

«Dear Mr. Plaxton: Thank you for your letter of 27 September [1988]. There are, unfortunately, two strong obstructions to my accepting to serve as a member in the Advisory Editorial Board of the projected journal Ecological Economics. But, to recall what Napoleon I once said, only one obstruction need be mentioned. In my own case, the advisory job would require time and my disposable time does not suffice to fulfill even my old commitments. » ${ }^{1}$

One might be intrigued by this declined invitation, and the non-stated second reason. Georgescu-Roegen was indeed identified as one of the "founding fathers" of the nascent field to which the journal was devoted. Published in 1971, his The Entropy Law and the Economic Process is today considered an "epoch making" contribution in the development of ecological economics (Røpke 2004, 296). In one of his most widely read

\footnotetext{
${ }^{1}$ Georgescu-Roegen to Ken Plaxton, 10 October 1988, Box 6, File “Invitation”, Nicholas Georgescu-Roegen's papers; Economists’ Papers Project; Rare Book, Manuscript, and Special Collections Library; Duke University (thereafter NGRP). Additional archival material and information on Georgescu-Roegen's critical views on ecological economics can be found in Bonaiuti (2001).
} 
Final draft version

articles, Georgescu-Roegen himself had expressed the view that "economics will have to merge into ecology" (Georgescu-Roegen 1975, 374). Yet, as this exchange of letters might reveal, and as this essay endeavors to clarify, dissensions existed as to what should be the proper relations between economics and ecology.

The self disfranchisement of Georgescu-Roegen from ecological economics has been attributed to his bitterness caused by "the failure of the profession to give his work the recognition that it truly merited, and in part by his own irascible and generally demanding personality" (Daly 1995, 154; Røpke 2004, 310-311). Not denying the possible role of those factors, we rather want to retrace how his insistence that a reversal of growth was inevitable, and his sharp criticism of any contribution suggesting a milder view on the topic, contributed to set him apart from the other critics of unbridled growth - as exemplified by his joining the Club of Rome (which commissioned the report Limits to Growth), soon followed by his resignation over this issue. Our aim here is not to chant the merits of la decroissance, or to rehabilitate Georgescu-Roegen as a heroic, misunderstood figure in science. We are more interested in the reasons which render a particular discourse successful or unsuccessful in the realm of environmental economic policy: why did Georgescu-Roegen judge that his views on the decline of the economy were not appropriately represented by the Club of Rome, and why were GeorgescuRoegen's views indeed difficult to translate into a practical economic policy.

By recounting the story of Georgescu-Roegen, we intend to nourish the current discussions about the possible relevance of a program of reversal of economic growth the purposeful decline of the human economy. In particular, this historical note intends to clarify how Georgescu-Roegen, often presented as a founding figure to this idea, came to 
Final draft version

formulate the central concept of the entropic nature of the economic process. We will first survey briefly the increasing concerns about the environmental impact of economic growth developing up to the 1970s, when articulated criticisms of economic growth emerged from within and without economic science, fueling discussions about which should be the ultimate target for economic policy. The second section will examine the origins and rationale of Nicholas Georgescu-Roegen's singular proposal in these debates - the diagnostic of the necessary decline of the economy, and a "bioeconomic program" to achieve it.

Next, we will relate the episode of Georgescu-Roegen's short-lived connection with the Club of Rome, an international group of decision-makers which sponsored the publication of Limits to Growths in 1972. This episode reveals the gap between Georgescu-Roegen's uncompromising attachment to de-growth, and the milder, more managerial approach to growth which characterized the Club of Rome. We conclude that the echo of this experience might well be a fundamental reason accounting for Georgescu-Roegen's later self-exclusion from the emerging ecological economics.

\section{Economic growth and its critiques in the 1970s}

Since the 1950's at least, the public opinion was regularly reminded that the increased pace of economic growth had damaging impact on the environment, with a measurable impact on public health. As environmentalist historian Thomas Dunlap put it:

Ecology, if not always by that name, became part of the school curriculum and popular nature entertainment - books, movies, television. It also came home. Radioactive isotopes from hydrogen bomb tests in the central Pacific 
Final draft version

appeared in food, including strontium-90 in that quart of milk nutritionists and the milk industry urged mothers to give their children everyday. Newspapers, magazines, and television provided what amounted to a short course in how the movement of atmosphere, food chains, and bioconcentration brought these products of modern science to you. (Dunlap 1999) $)^{2}$

Reserves of natural resources had been scrutinized by the presidential Paley Commission. In its report published in 1952, the commission estimated the growth of the demand for materials and energy for the American economy. It formulated recommendations for a prudent use of those resources, but did not emit skeptical conclusions. An outgrowth of the conference was the foundation of Resources For the Future, a think tank focusing on environmental issues which issued several influential pamphlets in the 1960s. Those pamphlets raised the consciousness on the issue of finite resources for the management of the economy, while keeping with rather optimistic predictions. ${ }^{3}$

The Sixties were also a time when the overlap between scientific practices and societal issues were intensively scrutinized. In the wake of a new environmental awareness, ecological concerns increasingly intersected with issues of race, politics, and gender. Energy policies encouraging the development of nuclear power plants and facing the hostility of local populations, industrial pollution in urban ghettos and suffered

${ }^{2}$ On the transformations of the American society and the rise of an environmental consciousness, see also Petulla (1987), Hays (1987) and Scheffer (1991).

${ }^{3}$ Barnett and Morse (1963), Jarrett (1966). This last volume is the one where Kenneth Boulding developed his metaphor of the "spaceship Earth". In this period, the book with the loudest impact is however the pessimistic Silent Spring by Rachel Carson (1962). 
Final draft version

disproportionately by minorities, or major disasters hitting developing countries, all suggested that the economy of nature and the human economy had complex intersects.

The field of economics came to terms in different ways with those developments. As a social science which had firmly established its credentials to expert knowledge at the service of the government in the last decades, "nature" was now defined as another economic problem tractable with the usual apparatus of the discipline. ${ }^{4}$ Nature and the environment, essentially ignored so far in economic models, were recast as productive resources (depletable or renewable) with their best use to be determined according to allocative or productive efficiency criteria. Oil depletion, threats to biodiversity and pollution were all redrawn as problems familiar to the economist: how best to contain them with regard to the benefits they provide, the scarcity of natural resources, and the cost of alternative resources? $?^{5}$ Dynamic subfields of the economics framed by this quasimanagerial approach to the environment first emerged in the 1970s and continue to this

\footnotetext{
${ }^{4}$ The economic approach to environmental issues of course originated much earlier in the century, under the discussions of externalities (Pigou 1920) and an early discussion of the problem posed by exhaustible resources (Hotelling 1931).

${ }^{5}$ Cost-benefit analysis took some time to be applied to environmental problems, because of a mutual distrust between environmentalists and economists. Historian of environmentalism Samuel Hays suggests that economists were slow to include environmental costs in their usual cost-benefit analysis, while economist Wallace Oates stresses that environmentalists were in any case refusing to rely on cost-benefit analysis (Oates 1992; Hays 1987). Two early reviews of environmental economics are Fisher and Peterson (1976) and Peterson and Fisher (1977), see also Clark (1976).
} 
Final draft version

day. The possibility that the starting point of neoclassical economics, namely, rational agents interacting in a competitive market economy, might be insufficient to deal with the consequences of pollution and overexploitation of "free" natural resources remained a disputed point. The famous paper by Ronald Coase on the "Problem of the Social Cost" seemed to suggest to contemporary readers that an administrative or judicial intervention to curb the activity of polluters, such as a Pigouvian tax, might be unnecessary or even have a counterproductive effect - without transaction cost, a bargaining between the polluter and the agents affected by the pollution might suffice. ${ }^{6}$

In parallel to those developments, some participants in the academic economic community conceptualized the environment in a manner that challenged the core assumptions of the discipline. In connection to the fundamental question of the desirability of economic growth, those participants questioned the isolation of economic science from broader social issues implied by the mainstream economic approach to the environment, such as consumerism. Kenneth Boulding, president of the American Economic Association in 1968, had authored in 1966 a memorable essay suggesting to abandon the traditional focus on local or national economic policies and the adoption of a ‘spaceship earth' standpoint instead. This new focus implied reconstructing economics by bringing the finiteness of the environment to the core of the discipline, rather than merely assuming than more always means better. According to this view, production and consumption, the cornerstones of classical and neo-classical economic analysis, should be

\footnotetext{
${ }^{6}$ See Coase (1960), Wellisz (1964), Mishan (1965). In fairness, a close reading of Coase shows a much more nuanced opinion on the desirability of governmental intervention
} (Medema 1994). 
Final draft version

removed from their central position. Instead of representing flows of goods to be maximized, they should be best seen as stocks to preserve (Boulding 1966; Daly 1968; Ayres and Kneese 1969). ${ }^{7}$ This new perspective on the economic cycle was not a merely a philosophical standing on the best way to enjoy life: its practical corollary was that GDP should not be maximized, even in first approximation. But what alternative should be pursued instead? Steady-state economy, sustainable growth, social growth, or limited growth were all discussed as plausible alternatives to the common wisdom of GDP maximization (Daly 1973; Hirsch 1976; Pirages 1977; Cleveland 1981), soon to be followed in 1987 by "sustainable development" - an expression which rallied most favors (Redclift 2005; but see Goodland and Daly 1996). One of the most radical alternatives was put forward by Nicholas Georgescu-Roegen, mathematician turned economist, who concluded that "undoubtedly, the current growth must cease, nay, be reversed." (Georgescu-Roegen 1975, p.369). In the following section of this essay, we endeavor to retrace the origins of such a radical proposal, looking at the entanglement of philosophical, economic and physical arguments developed by a man who described himself as an "emigrant from a developing country".

\footnotetext{
${ }^{7}$ More radically inclined economists questioned the political neutrality of the economic scientific discourse on environmental issues, pointing to the low valuation of environmental resources in a free market economy, and the role of economists in legitimating this type of economic system. Their conclusion was that both economic policies, and economic theory, were in need of reform - a possible future agenda of ecological economics (see Mata 2005).
} 
Final draft version

\section{Georgescu-Roegen: from mathematical economist to "economic myths" buster}

Nicholas Georgescu-Roegen was born in 1906 in Romania. ${ }^{8}$ Major of the aggregation exam in mathematics in 1927, he studied statistics in La Sorbonne in Paris and in the Galton Laboratory in London before spending 18 months at the economics department in Harvard (late 1934 - spring 1936). While in Harvard, Georgescu-Roegen published four articles, all dealing with the difficulties posed by the rigorous application of mathematics to the subject of economics. In a now classic contribution in pure economics aiming at incorporating fixed coefficients in the analysis of production, Georgescu-Roegen closed the article on a less than triumphal note, wondering whether economics really needed "so many purely mathematical generalizations?” (Georgescu-Roegen 1935, 49).

These were not mere claims of modesty from a mathematician turned economist. Georgescu-Roegen genuinely wondered about the adequacy of mathematical models to represent social reality. His doubts came to be reinforced by his coming back to Romania in 1936, where he would remain for the next twelve years. The still underdeveloped Romanian economy seemed not to accord to the most basic predictions he had learned from marginal theory. After a near escape from the communist regime in 1948, he returned to the United States, ignorant of the changes which had transfigured the economic profession since he had left. Whereas economics had previously assumed many forms which coexisted relatively peacefully in the prewar period, by the late 1940s a rigid orthodoxy had emerged, organized around the principle of marginal analysis and the

\footnotetext{
${ }^{8}$ On the life and work of Nicholas Georgescu-Roegen, see his autobiographical accounts (Georgescu-Roegen 1988; 1992; 1993) and Gowdy and Mesner (1998); Mirowski (1992); Bonaiuti (2001); Mayumi (2001) and Caré (2009).
} 
Final draft version

increasing use of mathematical formalism in the treatment of economic problems, conveniently designated by the label of "neoclassical economics" (Morgan and Rutherford 1998):

Soon after returning to the United States, I informally presented that idea [of marginal pricing being the worst policy for an agrarian overpopulated economy - NGR] at an after-dinner chat at the University of Chicago. How well I remember that there were absolutely no questions at the end! Those good friends wanted to spare me the embarrassment of being exposed as a neoclassical ignoramus.(Georgescu-Roegen 1992, 156).

After a two-year stint at Harvard where he collaborated with Wassily Leontief at the Harvard Economic Research Project, Georgescu-Roegen moved to Vanderbilt University in 1949, where he continued his pre-war examination of various branches of mathematical economics, raising the same strong doubts on the relevance of the overall enterprise - expressing what were considered then to be heterodox views. ${ }^{9}$ His criticisms focused on a set of properties which were imperfectly taken into account by neoclassical models, namely irreversibility of economic phenomena, qualitative change and radical uncertainty.

Georgescu-Roegen published his conclusions for the first time in Analytical Economics: Issues and Problems (1966) and then in a developed form in The Entropy Law and the Economic Process (1971), which identified the crux of the problem: social (and biological) reality was not to be captured by laws inspired from mechanics (Georgescu-

${ }^{9}$ His works with Leontief were published in an important collection of essays in operations research (Koopmans 1951). On this episode, see Akhabbar (2005). 
Final draft version

Roegen 1966). In addition to the basic inadequacies of "arithmomorphism", as he termed the tendency to impoverish reality by translating it into numbers, Georgescu-Roegen underlined the conflation of numerical representation with mechanism - the conception of a world ruled by unchanging relations between variables. This, he indicted, condemned economics to deny the emergence of novelty, and the flow of historical time. Only a non-mechanical law could represent a time's arrow, Georgescu-Roegen argued, like the second law of thermodynamics (or entropy law): it states that with time passing, energy is conserved, but undergoes an irrevocable qualitative degradation (energy is “dissipated," entropy increases), hence drawing an unequivocal, forward-looking time's arrow.

Such an interpretation of the entropy law was not uncontroversial even in physics. In fact, Ludwig Boltzmann's statistical interpretation of entropy had precisely arisen as an objection to this disturbing possibility of a law of nature which would be out of the reach of mechanics. In an attempt to reconcile entropy with mechanics, Boltzmann argued that the increase in entropy represented the convergence of a system toward its most probable state. In the instance of a gas, the chaotic state of particles was the most probable configuration; hence the associated macro-state had a high probability to occur. To make a long counter argument short, Georgescu-Roegen's dissent from this reading of entropy can be put in a graphical manner: if it were a matter of probability that disordered states happen to be more frequent than organized ones, then one should be able to witness in some infrequent cases some reversal of the process (see Figure 1). 
Final draft version

\section{Figure 1}

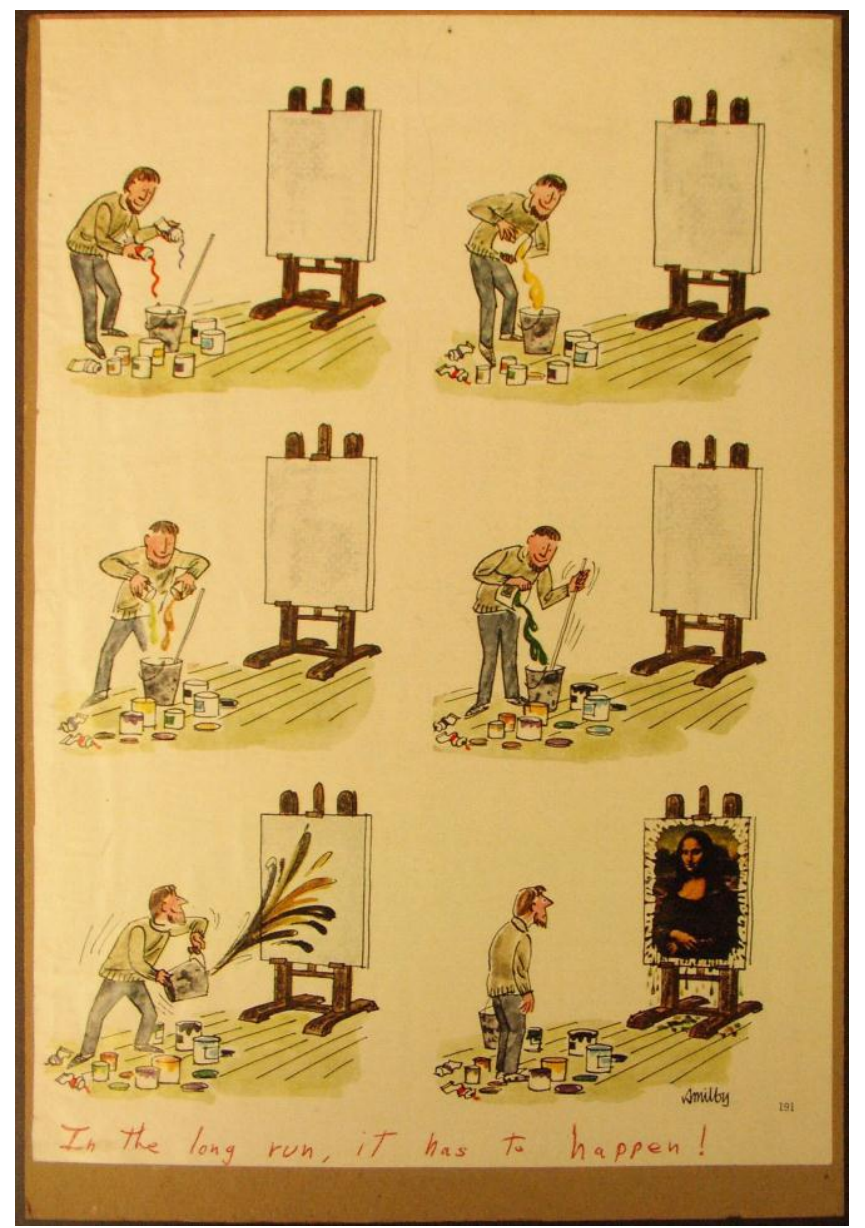

The caption reads: "In the long run, it has to happen!" This clipping found in Nicholas Georgescu-Roegen's papers illustrates his criticism of the statistical conception of entropy: rescuing mechanism by abandoning strict determinism allowed for some implausible implications. Source: clipping pasted on cardboard, n.d., in Box 6, Folder "Cartoon", NGRP. The folder contains other clippings representing very implausible, funny situations.

To my knowledge, no reviewer or commentator came forward to contest GeorgescuRoegen's arguments against the conception of entropy developed in statistical mechanics, or the similar charges he raised against the interpretation of information as negative entropy (Shannon and Weaver 1949; Georgescu-Roegen 1971, 401-406). This absence of rebuttal should probably not be taken as an endorsement however, and it is more likely that the unquestionable successes of mechanical statistics and Shannon and Weaver's 
Final draft version

theory of communication had made their criticisms largely irrelevant to contemporary scientists.

But from this theoretical discussion of entropy and the insistence on the existence of irreversible processes, Georgescu-Roegen drew very direct implications for economics. Irreversibility, he argued, cannot be safely ignored: the same way "life" is an irreversible process that can hardly be looked over by biologists, the irreversible depletion of energy and mineral resources should be given full attention by economists.

If the economic process is an entropic one, economic growth should be curbed or even reversed, in order to stop the "waste" of energy in "non-necessary" uses, so as to preserve it for the sake of future generations.

This conclusion raises at least two questions, to which Georgescu-Roegen provided answers which many found unconvincing. What is the rate of this entropic decay? And if we accept that it is necessary to economize on natural resources, to which level of economic activity should we be ready to scale down our current societies? The answer to the first question is unknowable, since the non-mechanical character of entropy makes an "entropymeter" inconceivable. This implies that it is impossible to predict whether it is our current generation or generations in the distant future who will be confronted with the direst consequences of the exhaustion of natural resources. ${ }^{10}$

To the second question, Georgescu-Roegen provided a logical answer: “... not only growth, but also a zero-growth state, nay, even a declining state which does not converge toward annihilation, cannot exist forever in a finite environment." (Georgescu-Roegen

\footnotetext{
${ }^{10}$ Many might find this last statement objectionable, yet the constant race between exhaustion of existing natural resources and new ways to exploit new ones (today nuclear fusion is the most discussed and anticipated, but the steam engine is another example) makes it impossible to make reasonable predictions on the timing of a fatal shortage of natural resources at the global scale.
} 
Final draft version

1975, p. 367). Since annihilation is presumably to be avoided, a declining state not converging towards annihilation would be the next most desirable one - and that amounts to converging towards some steady state, notwithstanding the sharp criticisms Georgescu-Roegen addressed to this notion (Georgescu-Roegen 1977a; Daly 1977; Georgescu-Roegen 1977b, see also the discussion in Kerschner 2008). ${ }^{11}$

One could have anticipated that the publication of The Entropy Law and the Economic Process would have sent shock waves in the profession. Nicholas Georgescu-Roegen, after all, was a major contributor to mathematical economics since the 1930's, and he had just been made a Distinguished Fellow of the American Economic Association. Yet, The Entropy Law did not trigger major debates in the mainstream of the profession. ${ }^{12}$ The

${ }^{11}$ This acknowledgment of the role of energy in maintaining economic life should not imply that Georgescu-Roegen was defending an energeticist conception of economic value. To the contrary, Georgescu-Roegen doubted the existence of any physical yardstick to measure value, and criticized repeatedly the attempts by H.T. Odum or Robert Constanza to design one. This became a central point of contention between Georgescu-Roegen and the contemporary critics of neoclassical economics (GeorgescuRoegen 1979; Mirowski 1988; Taylor 1988; Martinez-Alier 1990). I thank Juan Martinez-Alier for encouraging me to stress this point.

12 "It is only fair to add that Georgescu-Roegen's later books have not been well received, or rather, have been respectfully received and quickly put away. For various complex reasons, not to mention the difficult style in which they are written and the intimidating references they contain to theoretical developments in physics and biology, these works have received virtually no critical discussion from economists." (historian of economics 
Final draft version

only review in a leading journal of the mainstream chose not to address the thesis of the book. Instead, it warned the readers of the Journal of Economic Literature against the "broad, simplified, and incorrect statements on scientific, philosophical, and economic topics ... [which] call into question, unfortunately, the validity of the important philosophical generalizations made by the author" (Adelman 1972) ${ }^{13}$.

However, Georgescu-Roegen received signs that some quarters of the economic community were ready to welcome him in their ranks. Boulding, who had evoked the economic relevance of the entropy law in his own writings, was "delighted ... to welcome Georgescu-Roegen to the heretical sect, which regards consumption as a bad thing" (Boulding 1972, 1099). The Entropy Law also received four favorable reviews in the Journal of Economic Issues, a journal sponsored by the Association for Evolutionary Economics and representing the old tradition of institutional economics, a heterodox current of thought by the 1970s (Schlegel et al. 1973).

Mark Blaug quoted in Daly $(1995,150))$. In private correspondence, Harry Johnson was one of the few economists to develop his critical views: "I have only one major question. It does not seem to me that man should really worry about the survival of his descendants a thousand or a million years ahead. Such is the uncertainty about the future, and so strong is the current evidence that man makes out somehow, as a species, even if not as a member of a particular tribe or racial group or nation, that a zero or negative rate of discount of the future would seem unjustified." (Johnson to Georgescu-Roegen, 6 April 1972, Box 1, File "Fan mail”, NGRP).

${ }^{13}$ Georgescu-Roegen issued a rejoinder (Georgescu-Roegen 1972). 
Final draft version

It is not sure that Georgescu-Roegen was ready to accept this partition of the discipline in the orthodox / heterodox divide, with his work falling in the latter category. Fellow of the Econometric Society and once called by Paul Samuelson "the scholar's scholar and an economist's economist," the intended audience for his book was the core of the profession, not its peripheral "sects." 14 Soon, an opportunity emerged to give more publicity to his theoretical claims. By partnering with the Club of Rome, the organization behind the publication of Limits to Growth in 1972, Georgescu-Roegen would find a wider audience to his theses, while the Club of Rome would gain in scientific respectability.

\section{Georgescu-Roegen and the defense of Limits to Growth}

One year after the publication of The Entropy Law, a team of scientists and engineers at the MIT published "Limits to Growth", a report commissioned by the Club of Rome. The Club of Rome was founded in 1968 by Aurelio Peccei, an Italian manager with ambitions for economic development planning at the global scale, and enough charisma to gather a

\footnotetext{
${ }^{14}$ In 1973-1974, Georgescu-Roegen discussed plans with Boulding, Daly, Robert
} Heilbroner and Dennis Pirages to create a society which Boulding tentatively called Society for Optimum Sustainability (S.O.S.). Georgescu-Roegen argued that their envisioned society (which he would prefer to call the Bioeconomic Society, or else the Society for Environmental Economics, S.E.E.) should develop strong ties with the American Economic Association, because "In the last analysis, our ulterior aim should be to make AEA SEE ..." (Georgescu-Roegen to Boulding, August 14, 1974, Box 1, Folder “Kenneth, Boulding”, NGRP). The plans seem to have faltered in 1974. 
Final draft version

"club" of international decision-makers around this objective. In 1970, when Peccei was despairing of finding a quantitative, scientific medium to express the sense of urgency he felt about the world's human and environmental predicament, Jay Forrester's computerassisted structural models came up as an ideal solution. Forrester was an MIT engineer turned systems analyst who, in the line of cybernetics, was convinced that "all technical, social, and biological activities share similar systemic structures.” (Elichirigoity 1999, 56). Limits to Growth ran on an amplified version of the program that Forrester had initially designed for business management and urban policy modeling (Forrester 1961; Forrester 1969; Forrester 1971). Revamped for the world economy by Donella Meadows, Dennis Meadows and their co-authors, the report predicted in its "standard [simulation] run" that "under the assumption of no major change in the present system, population and industrial growth will certainly stop within the next century, at the latest", a prediction accompanied by a graph suggesting that industrial output per capita would peak in the early twenty-first century (Donella H. Meadows et al. 1972, 129-132). Benefiting from a great deal of publicity spurred by a skilful marketing, the report gained an even wider popularity when the first oil crisis (winter 1973-1974) emphasized the dependency of Western societies on oil. The report triggered intense debates in the media because of the seeming inevitability of its pessimistic conclusions, which many thought were simply deriving from an assumption of fixed technology. ${ }^{15}$

15 This argument was made by economist Carl Kaysen (1999), then Director of the Institute for Advanced Study at Princeton, in an influential review. Technological advance was taken into account in a modified version of their model by the Meadows 
Final draft version

The methodology of the report came under heavy criticism from the community of economists. In their professional meetings and journals, economists pointed to the distinction between physical scarcity (of course inescapable) and economic scarcity, the latter being mitigated by the adaptations of the productive capacity and the demand behavior brought by the price mechanism. With exhaustible resources becoming scarcer, their marginal productivity would increase (as reflected in their rising price), triggering the search for more efficient production techniques, substitution to cheaper and more widely available inputs, increase in recycling rates, and still other mechanisms. Positive levels of consumption could be maintained ad infinitum, and a smooth adaptation would take place instead - as economies have virtually always evolved. In December 1972, Robert Solow devoted his Richard T. Ely Lecture to refute the arguments of Limits to Growth, and in 1974 the Review of Economic Studies published papers from a symposium on "The Economics of Exhaustible Resources," which demonstrated that under plausible conditions, an optimal path of consumption of exhaustible resources could be drawn (Solow 1974a; Solow 1974b; Erreygers 2009).

In the attacks that economists launched on Limits to Growth, Georgescu-Roegen recognized the criticism that had failed to be addressed to his The Entropy Law. Joining the debate on Limits to Growth would demonstrate that his own theoretical conclusions were not mere flights of fancy of an isolated individual, but an issue meeting with considerable echo in the contemporary society. In return, his siding with Limits to

group: the grim predictions do disappear, and growth appears to meet no limit at a foreseeable horizon (year 2100). See Meadows (1974), esp. Figure 7-24 on p. 526. 
Final draft version

Growth would provide the Club of Rome with the much needed support and legitimacy of a well-respected professional economist.

In November 1972, Georgescu-Roegen' first helping hand to the Club of Rome was to give a talk at a conference organized by the School of Forestry and Environmental Studies at Yale University devoted to recording the reactions to Limits to Growth. A few days after, he approached the Meadows group, informing them that he had spent his presentation at Yale "criticiz[ing] most of those who have denounced The Limits to Growth by standard economic arguments, [s]ome of whom have spread around the thickest pollution of insults unmatched in the history of academic life." He was ready to go further and write a more thorough rebuttal of the Limits to Growth's critics, which would require Dennis Meadows to send to him "all other critical comments presented in print by economists, regardless of whether they accept or reject the argument of Limits to Growth."16

This offer to help with the economic side of the argument was all the more welcomed that, as Meadows replied to him, "Your analysis of the entropic nature of resources has had a substantial influence on the thinking of the members of my group". ${ }^{17}$ GeorgescuRoegen was glad to receive an abundance of material from Meadows and started

${ }^{16}$ Both quotes from Georgescu-Roegen to Dennis Meadows, 14 November 1972, Box 2, File "Meadows, Dennis", NGRP.

17 Dennis Meadows to Georgescu-Roegen, 27 November 1972, Box 2, File "Meadows, Dennis", NGRP. No publication by Georgescu-Roegen is referenced in Limits to Growth. This is especially through Herman Daly's works that Dennis Meadows got familiar with Georgescu-Roegen's positions (Dennis Meadows, email to the author, 23 March 2008). 
Final draft version

expanding his Yale lecture into an article summarizing his main conclusions, linking them to a defense of Limits to Growth. The article appeared in the Southern Economic Journal in 1975 under the title "Energy and Economic Myths."

In his essay, Georgescu-Roegen did not examine the details of the global computer model ("World 3") that yielded the quantitative predictions of Limits to Growth. He took a step back, indicting the economists for being "stubbornly attached" to the "mechanistic epistemology" (Georgescu-Roegen 1975, 347). This attachment made them ready to accept the principle of the conservation of energy, and its corollary, the maximization principle, but blinded them to the possibility of the exhaustion of natural resources. This is why economists were so keen on putting their trust in the existence of unknown reserves of energy yet to be discovered, substitution of new types of resources when the traditional one will be depleted, the increase in productivity and the reduction of waste, or the future harnessing of nuclear fusion. To those arguments, Georgescu-Roegen invariably replied that the stock of available and accessible energy being finite, mankind would by necessity one day face a shortage of energy and an accumulation of pollution: it was just a matter of time.

He did not forget to explicitly refer to the debate on Limits to Growth. "Curiously", Georgescu-Roegen noted, the recent publication of a report caused "an unusual commotion within the economics profession" (Georgescu-Roegen 1975, 364). How is it, he wondered, that a profession which spent the last thirty years promoting models replete with structural equations and computer simulations would object when the same kind of models were used by the team of MIT scientists who authored Limits to Growth? Indeed, Georgescu-Roegen admitted that some particular conclusions of the report could be 
Final draft version

called in question: "The much publicized conclusion - that at most hundred years separate mankind from an ecological catastrophe - lacks a scientifically solid basis." And yet, “it would be madness to ignore the study's general warnings about population growth, pollution, and resource depletion.” (Georgescu-Roegen 1975, 366).

To conjure the too-rapid exhaustion of its "dowry" in mineral resources by mankind, Georgescu-Roegen suggested a "bioeconomic program." Presented as minimal, it nevertheless comprised eight ambitious measures all aiming at economizing mineral resources. The first element of the list was the proposal that "the production of all instruments of war, not only war itself, should be prohibited completely." Then, "the underdeveloped nations must be aided to arrive as quickly as possible at a good (not luxurious) life," to be achieved notably by the free movement of people across borders. (Georgescu-Roegen 1975, 377-378). The list also included the control and progressive decrease of world population, and various appeals to stop the wasteful use of fashionable, ephemeral gadgets in everyday life. The eclectic nature of this economic program - from the abolition of wars to the termination of fashion - was the first hint that GeorgescuRoegen had an uncompromising view of what should follow from his theoretical conclusions. More to the point, this program dismissed the issue of how best to "doctor" growth, urging instead to implement what his pure logic dictated - negative growth in order to downsize the economy to the point where it taps a very minimum of exhaustible resources. The radical character of this standpoint should explain why the proposal for a purposeful decline of the economy, if achieved by the means he suggested, remained unexplored as a feasible economic and environmental policy proposal: in societies grounding their economy in the accumulation of capital and recently evolved into mass 
Final draft version

consumption societies, Georgescu-Roegen's bioeconomic program was simply not practical.

Nevertheless, the article was a success. One year after its publication, Georgescu-Roegen had sent over a thousand offprints to correspondents. In 1976, "Energy and Economic Myths" was reprinted in an edited volume with the eponymous title, which suggests that the decision to publish it was taken in relation with the success of the article. ${ }^{18}$ Georgescu-Roegen had eventually found an audience for his bioeconomics, once it was associated to the current debate on Limits to Growth. As to the Club of Rome, its steering committee must have been satisfied by the quality of this support since they decided to invite him to become a member of their very private group (limited to 150 members for its American branch at the time) in October $1977 .{ }^{19}$

And yet, in his very application letter to the U.S. Association for the Club of Rome, Georgescu-Roegen manifested some signs of wariness: "I cannot refrain, however, from expressing on this occasion my feelings that after the first report - by Meadows et al -

${ }^{18}$ On the offprints: Georgescu-Roegen to E.U. Kauer, 30 March 1976, Box 6, File "Reprints Requested 1971 / 1976", NGRP. The audience found by the article might have been widened thanks to science writer Nicholas Wade who made a particularly didactic and concise presentation of Georgescu-Roegen's bioeconomics for Science. See Wade (1975). In total, 1500 offprints were sent to correspondents. See Nicholas GeorgescuRoegen, “Quo Vadis Homo Sapiens Sapiens," typed draft dated 16 December 1989, p. 9. I thank John Gowdy for providing me a copy of this document.

19 Antonie Knoppers to Georgescu-Roegen, 3 October 1977; Donald Lesh to GeorgescuRoegen, 28 November 1977; Box 6, File “Club of Rome”, NGRP. 
Final draft version

the Club has taken a direction that is almost identical to that of standard economists, who claim that with their models and their computers they can bring about the economic New Jerusalem."20 Indeed, with the years passing, the divergence between GeorgescuRoegen's uncompromising view that growth should be reversed, and the milder statements by the rest of the Club of Rome, would increase.

Following Limits to Growth, ten new reports were commissioned by the Club of Rome from 1972 to 1980 . Each report drifted further away from the first report's concern with some material limits to growth. Two years after Limits to Growth, Mankind: The Turning Point relied on more complex computer models and more detailed data series, introducing a hierarchy of seven "systems strata" and ten geographical regions, to achieve four harmless conclusions, none of them even referring to a need to curb growth. $^{21}$ This mild view on growth, to be contrasted with Georgescu-Roegen's aggressive stance on the subject is due to the very different nature of the two corresponding approaches to scientific knowledge and public policy.

Georgescu-Roegen's intellectual background was foreign to the intellectual underpinnings of the Club of Rome's project and to the contemporary role of the scientist

${ }^{20}$ Georgescu-Roegen to Knoppers, 17 November 1977, Box 6, File "Club of Rome", NGRP.

${ }^{21}$ The following reports, in the words of a reviewer, were "each more florid but less striking in language than its predecessor. However grotesquely, rhetorical excess pays tribute to the problematique, even as it documents a retreat, report by report, into the safe, comfortable world of liberal sensibilities, fixed on the idea that articulation of any problem is at least half the battle in solving it." (Greenwood Onuf 1983, 138). 
Final draft version

as a manager and expert in public policy. His earlier interests in pure mathematics, then in pure economics, and finally in philosophy of science, provided Georgescu-Roegen with a sense of complete freedom and necessary "brutal honesty" in the derivation of the public policy recommendations stemming from his theoretical conclusions. Meanwhile, in the words of historian Fernando Elichirigoity, the Club of Rome was an enterprise of "planet management", looking for technocratic ways to monitor growth - certainly not to abolish it. ${ }^{22}$ The reasons for the growing sense of isolation of Georgescu-Roegen should now emerge. Georgescu-Roegen was keen on acknowledging the need for an integrated view of human and non-human spheres, as testified by his inclusion of biological and economic structures under the same entropic law. Yet, he did not share the technological optimism so characteristic of American post-war science, and which infused Limits to Growth. Open divergences finally appeared in the early 80's, when Georgescu-Roegen made clear that he had had different expectations:

“... I had since long grown out of sympathy with the activity of the Club itself and more so with the Association. After the report of the Meadows group, the Club began 'dancing' around the computers, instead of moving in force to take the banners against the

\footnotetext{
${ }^{22}$ In this respect, it is telling that when the French translation of "Limits to Growth" came out with the title "Halte à la croissance" ("Stop to Growth"), it was judged a very unfortunate title by the original authors of the report (Delaunay 1972; Elichirigoity 1999).
} 
Final draft version

production of armaments, against luxurious waste of natural resources by the developed economies, against the dreadful inequalities among nations."23

\section{Conclusion}

Georgescu-Roegen's The Entropy Law and the Economic Process was published in 1971, a few months before Limits to Growth. They both questioned the assumption made by nearly all currents in economics that the expansion of GDP was the ultimate goal of economic policy. We argued that because of the lack of attention that his book met from neoclassical economists, Georgescu-Roegen developed a defensive alliance with the Club of Rome. In participating in the noisy debate around the Limits to Growth report, Georgescu-Roegen could break the quasi silence that had welcomed the publication of his book in mainstream economics. Meanwhile, the Club of Rome, often targeted for the amateurism of the methodology displayed in their first report, could enroll GeorgescuRoegen, whose scientific credentials were impeccable.

The alliance was effective; however, it did not last. Georgescu-Roegen soon reproached the Club of Rome altogether for shying away from adopting a clear negative-growth slogan, their growing fascination for intricate computer-based models - and their appetite for public relation operations. An examination of the vastly different background of both enterprises - Georgescu-Roegen's journey as a theorist and a philosopher of science, leading to his formulation of bioeconomics, and the technocratic origins of the Club of

${ }^{23}$ Handwriting signed by Georgescu-Roegen, at the bottom of a letter dated 8 December 1981 from the US Association for the Club of Rome, enquiring about the non payment of the subscription for the current year (Box 6, File "Club of Rome", NGRP). 
Final draft version

Rome - provided a sense of the broad gap which separated Georgescu-Roegen from his contemporaries. Whereas he always doubted the power of mathematical and technical apparatus to represent and manage social reality, the Club of Rome precisely trusted the capacity of expertise and scientific management to bring solace to environmental and societal concerns. Archives do not speak by themselves, and neither does the following letter, but it can surely be read as a confirmation to our conclusion, and as an answer to the question introducing this essay: "There was also a long list of approached scholars to serve as Editorial advisors [to Ecological Economics]. It included my name but I declined Daly's invitation because there were already a number of other 'global' societies of the same kind talking only and even that in the wrong direction." ${ }^{24}$ From this new angle, it will appear that the estrangement of Georgescu-Roegen from ecological economics in the 80 's does not merely reflect the lapses of a difficult character, but might also reflect his disillusionment with what he perceived to be a lack of commitment to the decline of the economy, which he first experienced with the Club of Rome.

${ }^{24}$ Georgescu-Roegen to James F. Berrry, May 20, 1991, reproduced in Bonaiuti (2001, 185). James F. Berry was a WWII veteran, peace and environmental activist living in Raleigh, NC. 
Final draft version

Acknowledgments.

In preparing this paper, I benefited from interviews with Herman Daly, Jean-Paul

Fitoussi, Mason Gaffney, René Passet and Fred Singer, and from correspondence with Nicolas Caré, Jacques Grinevald, Andrea Maneschi, Juan Martinez Alier and Isabelle Stengers. This paper has been presented in earlier versions at the external seminar of the Economics Department at City University London in May 2008 and at the annual meeting of the History of Economics Society at Toronto in June 2008, where I received many valuable suggestions. As always, Philippe Fontaine provided rich comments on the writing of the paper. It should be clear that I remain sole responsible for the views held in this paper, and that the persons acknowledged here may well disagree with the interpretations I make. I am grateful to the Economics Department of Duke University for a grant to research the papers of Nicholas Georgescu-Roegen at the Economists' Papers Project in August 2006, and to City University London, ERIM and the Agence Nationale pour la Recherche (ANR) for financial support.

References

Adelman, Frank L. 1972. Review of 'The Entropy Law and the Economic Process'. Journal of Economic Literature 10, no. 2 (June): 458-460.

Akhabbar, Amanar. 2005. Is the Constancy of Technical Coefficients a Matter of Tolerance? Leontief and the Cowles Commission's Econometricians. Univ. Paris I working paper.

Ayres, Robert U., and Allen V. Kneese. 1969. Production, consumption, and externalities. American Economic Review 59, no. 3 (June): 282-297.

Barnett, H. J., and C. Morse. 1963. Scarcity and Growth: The Economics of Natural Resource Availability. Baltimore: John Hopkins University Press.

Bonaiuti, Mauro. 2001. La Teoria Bioeconomica. La «Nuova Economia» di Nicholas Georgescu-Roegen. Roma: Carocci.

Boulding, Kenneth E. 1972. Review of 'The Entropy Law and the Economic Process' [Search for time's arrow]. Science 174, no. 4026 (March 10): 1099-100.

Boulding, Kenneth E. 1966. The Economics of the Coming Spaceship Earth. In Environmental Quality in a Growing Economy, ed. Henry Jarrett. Baltimore: John Hopkins Press. 
Final draft version

Caré, Nicolas. 2009. Nicholas Georgescu-Roegen et sa Bioéconomie (1906-1955).

Master's dissertation, Université Charles-de-Gaulle.

Carson, Rachel. 1962. Silent Spring. Boston: Houghton Mifflin.

Clark, Colin W. 1976. Mathematical Bioeconomics: The Optimal Management of Renewable Resources. New York: Wiley \& Sons.

Coase, Ronald H. 1960. The problem of social cost. The Journal of Law and Economics 3, no. 1 (January 1): 1-44.

Daly, Herman E. 1968. On economics as a life science. Journal of Political Economy 76, no. 3 (June): 392-406. 1977. Letter to the Editor. Bioscience 27, no. 12 (December): 770-771. 1995. On Nicholas Georgescu-Roegen's contributions to economics: An obituary essay. Ecological Economics 13, no. 3 (June): 149-54.

Delaunay, Janine, ed. 1972. Halte à la Croissance? Enquête sur le Club de Rome. Paris: Le Club Français du Livre.

Dunlap, Thomas. 1999. Nature and the English Diaspora: Environment and History in the United States, Canada, Australia, and New Zealand. Cambridge: Cambridge University Press.

Elichirigoity, Fernando. 1999. Planet Management: Limits to Growth, Computer Simulation, and the Emergence of Global Spaces. Evanston: Northwestern University Press.

Erreygers, Guido. 2009. Hotelling, Rawls, Solow: How exhaustible resources came to be integrated into the neoclassical growth model. History of Political Economy 41 (January 1): 263-281. doi:10.1215/00182702-2009-027.

Fisher, Anthony C., and Frederick M. Peterson. 1976. The environment in economics: A survey. Journal of Economic Literature 14, no. 1 (March): 1-33.

Forrester, Jay. 1961. Industrial dynamics. Cambridge Mass.: M.I.T. Press. . 1969. Urban dynamics. Cambridge Mass.: M.I.T. Press.

- 1971. World dynamics. Cambridge Mass.: Wright-Allen Press.

Georgescu-Roegen, Nicholas. 1935. Fixed coefficients of production and the marginal productivity theory. Review of Economic Studies 3, no. 1 (October): 40-49. 1966. Analytical Economics: Issues and Problems. Cambridge: Harvard University Press.

- 1971. The Entropy Law and the Economic Process. Cambridge: Harvard University Press.

- 1972. Comment of Adelman's review. Journal of Economic Literature 10, no. 4 (December): 1268.

. 1975. Energy and economic myths. Southern Economic Journal 41, no. 3 (January): 347-381.

. 1977a. The steady state and ecological salvation: A thermodynamic analysis. Bioscience 27, no. 4 (April): 266-270.

. 1977b. Letter to the Editor. Bioscience 27, no. 12 (December): 771. 1979. Energy analysis and economic valuation. Southern Economic Journal 45, no. 4 (April): 1023-1058. 1988. An emigrant from a developing country: Autobiographical notes - 1 . Banca Nazionale del Lavoro Quarterly Review 164 (March): 3-31. . 1992. Nicholas Georgescu-Roegen about Himself. In Eminent Economists: Their 
Final draft version

Life Philosophies, ed. Michael Szenberg. Cambridge, UK: Cambridge University Press.

1993. An emigrant from a developing country: Autobiographical notes - 2 .

Banca Nazionale del Lavoro Quarterly Review 184 (March): 3-30.

Goodland, Robert, and Herman Daly. 1996. Environmental Sustainability: Universal and Non-Negotiable. Ecological Applications 6, no. 4 (November): 1002-1017.

Gowdy, John, and Susan Mesner. 1998. The Evolution of Georgescu-Roegen's

Bioeconomics. Review of Social Economy 56, no. 2: 136-156.

Greenwood Onuf, Nicholas. 1983. Review of 'Reports to the Club of Rome'. World Politics 36, no. 1 (October): 121-46.

Hays, Samuel P. 1987. Beauty, Health, and Permanence: Environmental Politics in the United States, 1955-1985. Cambridge: Cambridge University Press.

Hotelling, Harold. 1931. The economics of exhaustible resources. Journal of Political Economy 39, no. 2 (April): 137-175.

Jarrett, Henry, ed. 1966. Environmental Quality in a Growing Economy. Baltimore: John Hopkins Press.

Koopmans, Tjalling C, ed. 1951. Activity Analysis of Production and Allocation. Cowles Commission Monograph No. 13. New Haven: Yale University Press.

Martinez-Alier, Juan with Klaus Schlüpmann. 1990. Ecological Economics: Energy, Environment and Society. 1987th ed. Oxford: Blackwell.

Mata, Tiago. 2005. Dissent in Economics: Making Radical Political Economics and Post Keynesian Economics, 1960-1980. London School of Economics and Political Science.

Mayumi, Kozo. 2001. The Origins of Ecological Economics: The Bioeconomics of Geogescu-Roegen: New York: Routledge.

Meadows, Dennis L. 1974. Dynamics of Growth in a Finite World. Cambridge: WrightAllen Press.

Meadows, Donella H., Dennis L. Meadows, Jørgens Randers, and William III Behrens. [1972] 1974. The Limits to Growth: A Report for the Club of Rome's Project on the Predicament of Mankind. Second edition. New York: Potomac Associates.

Medema, Steven G. 1994. The myth of two Coases: What Coase is really saying. Journal of Economic Issues 28, no. 1 (March): 208-217.

Mirowski, Philip. 1988. Energy and energetics in economic theory: A review essay. Journal of Economic Issues 22, no. 3 (September): 811-830.

—. 1992. Nicholas Georgescu-Roegen. Research in the History of Economic Thought and Methodology: 86-105.

Mishan, E. J. 1965. Reflections on recent developments in the concept of external effects. The Canadian Journal of Economics and Political Science / Revue canadienne d'Economique et de Science politique 31, no. 1 (February): 3-34.

Morgan, Mary S, and Malcolm Rutherford, eds. 1998. From Interwar Pluralism to Postwar Neoclassicism. History of Political Economy Annual Supplement to volume 30. Durham-London: Duke University Press.

Oates, Wallace E., ed. 1992. The Economics of the Environment. Aldershot: Edward Elgar.

Peterson, Frederick M., and Anthony C. Fisher. 1977. The exploitation of extractive resources: A survey. Journal of Economic Literature 87, no. 348 (December): 
Final draft version

681-721.

Petulla, Joseph M. 1987. Environmental Protection in the United States: Industry, Agencies, Environmentalists. San Fransisco: San Fransisco Study Center.

Pigou, Arthur C. 1920. The Economics of Welfare. London: Macmillan.

Redclift, Michael. 2005. Sustainable development (1987-2005): An oxymoron comes of age. Sustainable Development 13, no. 4: 212-227.

Røpke, Inge. 2004. The early history of modern ecological economics. Ecological Economics 50, no. 0 (October): 293-314.

Scheffer, Victor B. 1991. The Shaping of Environmentalism in America. Seattle: University of Washington Press.

Schlegel, Richard, Ralph W. Pfouts, Werner Hochwald, and Glenn L. Johnson. 1973. Four reviews of Nicholas Georgescu-Roegen: 'The Entropy Law and the Economic Process'. Journal of Economic Issues 7, no. 3 (September): 475-499.

Shannon, Claude E, and Warren Weaver. 1949. The Mathematical Theory of Communication: Chicago: University of Illinois Press.

Solow, Robert M. 1974a. Intergenerational Equity and Exhaustible Resources. The Review of Economic Studies 41: 29-45. . 1974b. The economics of resource or the resources of economics. American Economic Review 64, no. 2 (May): 1-14.

Taylor, Peter J. 1988. Technocratic optimism, H.T. Odum, and the partial transformation of ecological metaphor after World War II. Journal of the History of Biology 21, no. 2 (Summer): 213-224.

Wade, Nicholas. 1975. Nicholas Georgescu-Roegen: Entropy the measure of economic man. Science 190, no. 4213 (October 31): 447-450.

Wellisz, Stanislaw. 1964. On external diseconomies and the government-assisted invisible hand. Economica 31, no. 124. New Series (November): 345-362. 